\title{
COPING WITH THE CHALLENGES IN TEACHING MAPEH SUBJECTS AMONG NON-SPECIALIZED TEACHERS OF DISTRICT 4 IN LAGUNA
}

\author{
Reem D. Montesur \\ Graduate School, Laguna State Polytechnic University, Santa Cruz, Laguna, Philippines
}

Article DOI: https://doi.org/10.36713/epra7323

DOI No: 10.36713/epra7323

\begin{abstract}
This study entitled coping with the challenges in teaching MAPEH subjects among the non-specialized teachers of District 4 in Laguna was conducted to specifically answer the following questions; What is the demographic profile of the Teachers in MAPEH in terms of; Age; Gender; Years in Service; Educational Attainment and Specialization? What is the coping mechanism of the Teachers in MAPEH in terms of: Time Management; Academic Advice and Mentoring; Appraisal Focused; Emotional-Focused; Occupation-focused coping? Do the coping mechanism used by teachers significantly affect the performance of non-specialized teachers teaching MAPEH of District 4 in Laguna?

The study utilized a descriptive design to determine the coping mechanism of the non-specialized teachers in MAPEH. The main source data of this study was the survey questionnaire which was prepared by the researcher and statistically treated by the use of simple descriptive statistics such as frequency, percentage and the mean to determine the significant effect on the performance of the non-specialized teachers in MAPEH of the District of 4 in Laguna.

In order to conduct this study, letters were sent to the Schools Divisions Superintendent Dr. Marites A. Ibanez, asking permission and approval to conduct the study, and to the School Principals of the selected schools, asking to distribute questionnaires to the ones teaching MAPEH.

Preparation of self-made questionnaire by the researcher followed. The researcher-made questionnaire was checked by the thesis adviser. Face validation of the contents of the questionnaire was done by the adviser of the researcher and other persons with specialization in the field. They were vital members of the education team.

Researchers use purposive sampling when they want to access a particular subset of people, as all participants of a study are selected because they fit a particular profile. Each individual was chosen entirely by chance and each member of the population had an equal chance of being included in the sample. The respondents of the study consisted of fifty non-major or non-specialized in MAPEH inn District 4 in Laguna.

The purpose of the study may offer literature and findings that may be useful in the conduct of future studies more particularly in the context of communication considering the stressor and how to cope with the challenges of the teachers in teaching a non-major subject.

Copies of the questionnaire were multiplied based on the number of the respondents. Then it was administered. With confidentiality, the gathered information was transferred in a tally sheet. Subsequently, codes were assigned to each indicator. The encoded data were given to the researcher's statistician for the descriptive analysis. The gathered data were interpreted and presented in textual and tabular forms and appropriate interpretation was made.

The methods used was statistical to analyze and interpret the data gathered, the weighted mean and the F-test formula which is the statistical test in which the test statistic has an F-distribution under the null hypothesis. It is most often used when comparing statistical models that have been fitted to a data set, in order to identify the model that best fits the population from which the data were sampled.

The implication of this research is to find out the importance of how teachers of MAPEH especially the non-majors become aware of learning and dealing with teaching challenges. Have an important mechanism for handling situations related to MAPEH teaching.

The result showed that the coping challenges in teaching MAPEH subjects had no significant effect on the performance of the non-specialize Teachers teaching MAPEH subjects of District 4 in Laguna, and therefore the hypothesis was also rejected.
\end{abstract}

KEYWORDS: Coping Challenges, Coping mechanism, Non-Specialized, MAPEH, Stressor 


\section{INTRODUCTION}

In the current situation of our educational system, many teachers are experiencing difficultiesi $n$ teaching and facing complicated challenges because of their inadequate training in the field to which they belong. Due to the fact that teachers are in demand, the fashion in teaching is very evident. Teaching is a profession that many teachers enjoy doing because of their love and commitment for the sworn duty. On the other hand, some teachers especially the new ones experience high level of stress. After first year of teaching, they leave the field of education due to lack of administrative support, inability to manage personal and professional expectations, limited teaching resources, lack of professional development, and difficulty in handling behavioral problems in the classroom. There is an increased rate of attrition by as much as $50 \%$ of teachers who leave teaching within the first three to five years (Le Maistre \& Paré, 2008).

It can be said that teaching has two faces: the experience that teaches how to learn and the experience that lead them to give up. In terms of learning, it can be said that one of the most important drivers for teachers to continue teaching is the students' achievements that they themselves have been instruments in their success. Teachers also referred to as novice teachers, if they are assigned to handle subjects they are not-specialized in most particularly teaching MAPEH components. A number of novice teachers are at high rates has. This situation has provoked administrators and other education planners to devise coping mechanisms. These mechanisms can be utilized by teachers as they begin their careers in the field of education. The concern of the teachers assigned in different specializations, with the lack of coping mechanisms is apparent in a specific sub-section within the education field, specifically, in geographical areas and subject, where these mechanism are highly needed. Offering a myriad of mechanisms to new teachers may help and support them to better assimilate to their new school cultures and roles. Implementation of these mechanisms has proven to be good approaches, which significantly have reduced the number of first year teachers who experienced frustration, unrewarding and intolerable difficulty throughout the school year, and desired or decided to leave the profession

Through this, a study of coping with the challenges in teaching MAPEH among nonspecialized teachers in the Junior High School of District 4 in Laguna is conducted. All tasks in teaching such areas and MAPEH component and their effects on the performance of teachers especially the non-specialized ones in teaching MAPEH will be determined.

\section{OBJECTIVES}

This study determined the coping mechanism in teaching MAPEH of the non-specialized teachers of District 4 in Laguna. Specifically, the study sought answers to the following questions:

1. What is the demographic profile of the Teachers in MAPEH in terms of;
1.1 Age;
1.2 Gender;
1.3 Years in Service;
1.4 Educational Attainment
1.5 Specialization;

2. What are the coping mechanism of the Teacher's in MAPEH in terms of:
2.1 Time management;
2.2 Academic advice and mentoring;
2.3 Appraisal focused;
2.4 Emotion focused;
2.5 Occupation- focused coping?

3. What is the performance of the non-specialized teachers in MAPEH in terms of;

3.1 Classroom management;

3.2 Coaches and Trainers;

3.3 Handling Ancillary Task?

4. Do the coping mechanisms used by teachers significantly affect the performance of non-specialized teachers teaching MAPEH of District 4 in Laguna?

\section{METHODOLOGY}

The researcher consulted her statistician on the sampling techniques. Purposive sampling, also known as judgmental, selective, or subjective sampling, is a form of non-probability sampling in which researcher relied on their own judgment when choosing members of the population to participate in their study. This sampling 


\section{EPRA International Journal of Research and Development (IJRD)}

method requires researchers to have prior knowledge about the purpose of their studies so that they can properly choose and approach eligible participants. Researchers use purposive sampling when they want to access a particular subset of people, as all participants of a study are selected because they fit a particular profile. Each individual was chosen entirely by chance and each member of the population had an equal chance of being included in the sample. The respondents of the study consisted of fifty non-major or non-specialized in MAPEH inn District 4 in Laguna.

In order to conduct this study, letters were sent to the Schools Divisions Superintendent Dr. Marites A. Ibanez, asking permission and approval to conduct the study, and to the School Principals of the selected schools, asking to distribute questionnaires to the ones teaching MAPEH.

Preparation of self-made questionnaire by the researcher followed. The researcher-made questionnaire was checked by the thesis adviser. Face validation of the contents of the questionnaire was done by the adviser of the researcher and other persons with specialization in the field. They were vital members of the education team.

The following statistical tools were used in order to analyze and interpret the gathered data:

Descriptive statistics were applied to properly derive information and frequency distributions of the gathered data. Weighted mean was used to find out the average responses of the respondents as measurement of the central tendency. F-Test Formula an F-test is any statistical test in which the test statistic has an F-distribution under the null hypothesis. It is most often used when comparing statistical models that have been fitted to a data set, in order to identify the model that best fits the population from which the data were sampled F Statistic variance of the group means / mean of the within group variances, was also utilized.

\section{RESULT AND DISCUSSION}

This chapter deals with the presentation, analysis and interpretation of data gathered to answer the sub problem relative to the main problem of this study on coping with the challenges in teaching MAPEH and its effect on the performance of the non-specialized teachers. This chapter discusses the findings of the study based on the research questions

\section{Demographic Profile of Teachers}

Figure 2. Demographic Profile of the Respondents in Terms of Age

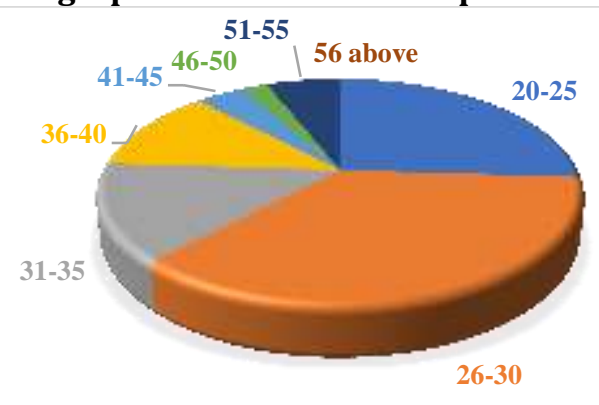

The data showed the age of fifty teachers, 13 of them ranged $20-25$ years old (26\%); 18 , from 26-30 years old (36\%); 7, from 31-35 years old (14\%); 6, from 36-40 years old (12\%); 2, from 41-45 years old (4\%); 1 , from 46-50 years old (2\%); and 3, 51-55 years old (6\%). This meant that teachers were generally young as evidenced in the profile in terms of age.

Figure 3. Demographic Profile of the Respondents in Terms of Gender

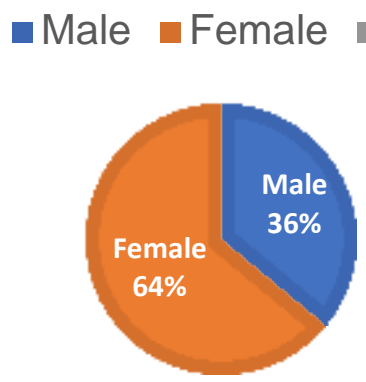




\section{EPRA International Journal of Research and Development (IJRD)}

Figure 4 below includes the data of the respondents in terms or the years in service. Five ( 5 years) had twenty five teachers ( 50\%); 6-10 years consisted of fourteen teachers $(28 \%) ; 11-15$ years had five teachers (10\%); 16-20 years had two (4\%); $21-25$ years had one teacher (2\%) and 26-30 years consisted of three teachers $(6 \%)$, lastly, in 31 years to 35 and 36 years above, had zero number of teachers.

Figure 4. Demographic Profile of the Respondents in Terms of Years in Service

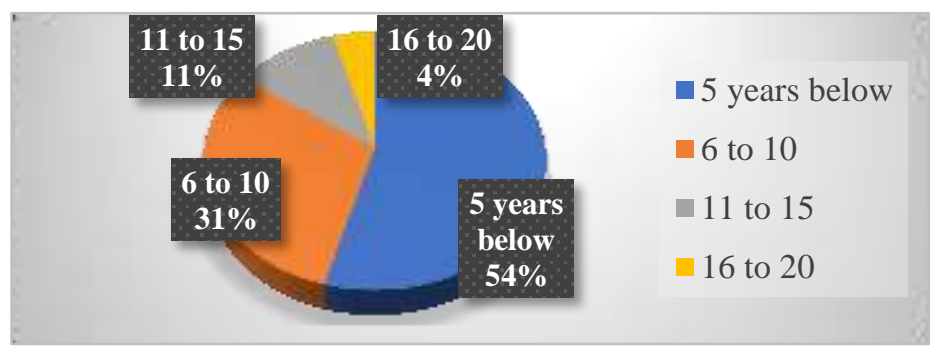

Figure 5 presents the demographic profile of the respondents in terms of educational attainment. Thirty five out of fifty respondents (70\%) had a bachelor degree; five (10\%) had Master of Education degree; no one had a doctorate degree and others ten $(20 \%)$.

Table 2. Demographic Profile of the Respondents in Terms of Specialization / Non-specialized

\begin{tabular}{ccc}
\hline Specialization & frequency & Percentage \\
\hline Non-Specialized & $\mathbf{5 0}$ & $100 \%$
\end{tabular}

The table above presents the demographic profile of the teacher-respondents indicating their specialization. It was stated that the teacher respondents were fifty (50) in frequency, one hundred $100 \%$ nonspecialized teacher-respondents.

Table 3. Presents the Coping Mechanism of the Non- specialized Teachers in Terms of Time Management

\begin{tabular}{clccc}
\hline \multicolumn{1}{c}{ Indicator } & Mean & SD & $\begin{array}{c}\text { Verbal } \\
\text { Interpretation }\end{array}$ \\
\hline 1. & Set goals and prepare lesson early. & 4.38 & 0.60 & Very Frequently \\
\hline 2. & $\begin{array}{l}\text { Organize and set priorities in teaching to } \\
\text { achieve the daily objectives in my lesson } \\
\text { exemplar. }\end{array}$ & 4.50 & 0.54 & Very Frequently \\
\hline 3. & $\begin{array}{l}\text { Make use of differentiated instruction in } \\
\text { every component of MAPEH in teaching. }\end{array}$ & 4.26 & 0.60 & Very Frequently \\
\hline 4. & $\begin{array}{l}\text { Maximize the time allotted in teaching my } \\
\text { lesson. }\end{array}$ & 4.32 & 0.62 & Very Frequently \\
\hline 5. & Prepare lesson ahead of time. & 4.42 & 0.73 & Very Frequently \\
\hline & Weighted Mean: SD & 4.38: 0.62 \\
\hline Verbal Interpretation & Very frequently \\
\hline
\end{tabular}

Table 3 presents the level of coping mechanism in terms of time management. Teachers set goals and prepared lesson early, $(\mathrm{M}=4.38, \mathrm{SD}=0.60)$ with verbal interpretation of Very Frequently. The teachers organized and set priorities in teaching to achieve the daily objectives of the lesson $(\mathrm{M}=4.50, \mathrm{SD}=0.54)$ with verbal interpretation of Very Frequently. They prepared lesson ahead of time $(\mathrm{M}=4.42, \mathrm{SD}=0.73)$. Teachers also made differentiated instruction in teaching every component of MAPEH $(\mathrm{M}=4.26, \mathrm{SD}=0.60)$. The weighted mean $(\mathrm{WM}=4.38, \mathrm{SD}=0,62)$ implied that non-specialized teachers of MAPEH applied strategies to cope with the challenges in teaching. They maximized time, set goal and priorities for the preparation of the lessons. The overall interpretation in all indicators was Very Frequently. 


\section{EPRA International Journal of Research and Development (IJRD)}

Table 4. Presents the Coping Mechanism of the Non- specialized Teachers in Terms of Academic Advice and Mentoring

\begin{tabular}{|c|c|c|c|}
\hline Indicator & Mean & SD & $\begin{array}{c}\text { Verbal } \\
\text { Interpretation }\end{array}$ \\
\hline $\begin{array}{l}\text { 1. Usually invite my Head Teacher to hear and } \\
\text { observe in my class. }\end{array}$ & 3.88 & 0.90 & Often \\
\hline $\begin{array}{l}\text { 2. Follow my mentor's advice for the } \\
\text { improvement of my personal and professional } \\
\text { growth in teaching MAPEH. }\end{array}$ & 4.58 & 0.57 & Always \\
\hline $\begin{array}{l}\text { 3. Perform collaborative discussions with my co- } \\
\text { teachers. }\end{array}$ & 4.36 & 0.75 & Always \\
\hline $\begin{array}{l}\text { 4. Consult my colleagues / mentors about my plan } \\
\text { for the subject which I do not understand } \\
\text { much. }\end{array}$ & 4.32 & 0.77 & Always \\
\hline $\begin{array}{l}\text { 5. Allow myself to do my mentors advice to } \\
\text { develop my strategies in teaching MAPEH. }\end{array}$ & 4.38 & 0.70 & Always \\
\hline Weighted Mean: SD & & & \\
\hline Verbal Interpretation & & & \\
\hline
\end{tabular}

Table 4 presents the level of coping mechanism of the non-specialized teachers in MAPEH in terms of academic advice and mentoring. The indicator included the teachers usually invited the head teacher to hear and observe their classes $(\mathrm{M}=3.88, \mathrm{SD}=0.90)$ interpreted as Often. The teachers followed their mentor's advice for the improvement of their personal and professional growth in teaching MAPEH $(\mathrm{M}=4.58, \mathrm{SD}=0.57)$ with verbal interpretation of Always. The teachers performed collaborative discussions with their co-teachers, $(\mathrm{M}=4.36$, $\mathrm{SD}=0.75)$ with verbal interpretation of Always. The teachers consult their colleagues/mentors about their plan for the subject which they did not understand much $(\mathrm{M}=4.32, \mathrm{SD}=0.77)$ with verbal interpretation of Always. The teachers allowed themselves to do their mentors' advice to develop their strategies in teaching MAPEH $(\mathrm{M}=4.38, \mathrm{SD}=0.70)$ with Always as the verbal interpretation. The Weighted Mean 4.30 and $\mathrm{SD}=0.77$ with an overall verbal interpretation of Always.

Table 5. Presents the Coping Mechanism in Terms of Appraisal Focused

\begin{tabular}{rlccc}
\hline \multicolumn{1}{c}{ Indicator } & Mean & SD & $\begin{array}{c}\text { Verbal } \\
\text { Interpretation }\end{array}$ \\
\hline 1. & Think carefully about the decision making to make. & 4.42 & 0.61 & Always \\
\hline 2. & $\begin{array}{l}\text { Consult my colleagues for proper solution to the } \\
\text { problem I encountered in teaching MAPEH. }\end{array}$ & 4.42 & 0.50 & Always \\
\hline 3. & $\begin{array}{l}\text { Tend to not react immediately in time of my } \\
\text { students' trouble or problem. }\end{array}$ & 4.10 & 0.97 & Often \\
\hline 4. & Apply sense of humor in teaching. & 4.28 & 0.78 & Always \\
\hline 5. & $\begin{array}{l}\text { Let my student evaluate my teaching at the end of the } \\
\text { class. }\end{array}$ & 4.04 & 0.86 & Often \\
\hline & Weighted Mean: SD & & $\mathbf{4 . 2 5 : 0 . 7 7}$ \\
\hline
\end{tabular}

Table 5 presents the level of coping mechanism in terms of appraisal focused. The indicators included that the teachers thought carefully about the decision making to make $(\mathrm{M}=4.22, \mathrm{SD}=0.61)$ with verbal interpretation as Always. The teachers consulted their colleagues for proper solution to the problem they encountered in teaching MAPEH $(\mathrm{M}=4.42, \mathrm{SD}=0.50)$ with verbal interpretation of Always. Teachers tended not to react immediately in times of their students trouble or problem $(\mathrm{M}=4.10, \mathrm{SD}=0.97)$.verbal interpretation of Often. The teachers applied sense of humor in teaching $(\mathrm{M}=4.28, \mathrm{SD}=0.78)$ interpreted as Always. They let the students evaluate the teachers in their teaching at the end of the class $(\mathrm{M}=4.04, \mathrm{SD}=0.86)$ with verbal 


\section{EPRA International Journal of Research and Development (IJRD)}

Volume: 6 | Issue: 6 | June 2021

- Peer Reviewed Journal

interpretation of often. The weighted mean resulted as 4.55 and SD of 0.77 with overall verbal interpretation of Always.

Table 6. Presents the Coping in Terms of Emotion-focused

\begin{tabular}{|c|c|c|c|}
\hline Indicator & Mean & SD & $\begin{array}{c}\text { Verbal } \\
\text { Interpretation }\end{array}$ \\
\hline 1. Practice the maximum tolerance in my profession. & 4.42 & 0.54 & Always \\
\hline 2. Find time to do some doings that makes me relax. & 4.36 & 0.69 & Always \\
\hline $\begin{array}{l}\text { 3. Have time to spend with my family and friend for some } \\
\text { small talk to ease stress. }\end{array}$ & 4.34 & 0.80 & Always \\
\hline 4. Eat a lot in time of hectic schedule. & 3.46 & 0.99 & Often \\
\hline $\begin{array}{l}\text { 5. Refuse to talk about my problem because I believe I } \\
\text { can find ways to solve it. }\end{array}$ & 3.92 & 1.01 & Often \\
\hline Weighted Mean: SD & \multicolumn{3}{|c|}{ 4.10: 0.90} \\
\hline Verbal Interpretation & \multicolumn{3}{|c|}{ Often } \\
\hline
\end{tabular}

Table 6 presents the level of coping mechanism of teachers in terms of emotion-focused coping. The five indicators and results were the following: The teachers practiced maximum tolerance in their profession $(\mathrm{M}=4.42, \mathrm{SD}=0.54)$, verbal interpretation of Always. They find time to do some doing to make them relax $(\mathrm{M}=4.46, \mathrm{SD}=0.69)$ always as its verbal interpretation. The teachers spent time with family and friends for some small talk to ease the stress $(\mathrm{M}=4.34, \mathrm{SD}=0.80)$ also with Always as verbal interpretation. The teachers ate a lot in times of hectic schedules $(\mathrm{M}=3.46, \mathrm{SD}=0.99)$ as Often. Lastly, the teachers refused to talk about their problems because they believed that they could find ways to solve them, $(\mathrm{M}=4.92, \mathrm{SD}=1.01)$ with the verbal interpretation of Often.

Table 7. Presents the Coping in Terms of Occupation-focused

\begin{tabular}{llccc}
\hline \multicolumn{1}{c}{ Indicator } & Mean & SD & $\begin{array}{c}\text { Verbal } \\
\text { Interpretation }\end{array}$ \\
\hline 1. & Capable to work at my own. & 4.20 & 0.73 & Often \\
\hline 2. & $\begin{array}{l}\text { Confident to teach MAPEH. I can positively influence } \\
\text { my students physically, mentally, emotionally and } \\
\text { spiritually. }\end{array}$ & 4.10 & 0.74 & Often \\
\hline 3. & Satisfied to the result of the outputs of my students. & 4.12 & 0.69 & Often \\
\hline 4. & $\begin{array}{l}\text { Able to execute the activities in teaching the four } \\
\text { components in MAPEH. }\end{array}$ & 4.18 & 0.69 & Often \\
\hline 5. & $\begin{array}{l}\text { Sure that my strategies use is effective in teaching } \\
\text { MAPEH. }\end{array}$ & 4.16 & 0.79 & Often \\
\hline & & & $\mathbf{4 . 1 5 : 0 . 7 2}$ \\
\hline
\end{tabular}

Table 7 consists of the results in the level of coping mechanism in terms of occupation-focused. It was stated that the teachers were capable to work at their own $(\mathrm{M}=4.20, \mathrm{SD}=0.73)$. The teachers were confident to teach MAPEH, they could positively influence the students physically, mentally, emotionally and spiritually $(\mathrm{M}=4.10, \mathrm{SD}=0.74)$. The teachers were satisfied to the results of the outputs of their students $(\mathrm{M}=4.12$, $\mathrm{SD}=0.69)$. The teachers were able to execute the activities in teaching the four components in MAPEH $(\mathrm{M}=4.18, \mathrm{SD}=0.69)$. The teachers were sure that their strategies used were effective in teaching MAPEH $(\mathrm{M}=4.16, \mathrm{SD}=0.79)$. The weighted mean result was 4.15 , with standard deviation of 0.72 and the overall interpretation results as Often. 


\section{EPRA International Journal of Research and Development (IJRD)}

Table 8. Performance of the Non-specialized Teachers in MAPEH as Classroom Managers

$\begin{array}{lccc}\text { Indicator } & \text { Mean } & \text { SD } & \begin{array}{c}\text { Verbal } \\ \text { Interpretation }\end{array} \\ \begin{array}{l}\text { As a Classroom Manager/ Adviser } \\ \text { rules and regulations inside the classroom and I }\end{array} & 4.32 & 0.6 & \begin{array}{c}\text { Always } \\ \text { Performed }\end{array}\end{array}$

review the rules and regulations to make sure they clearly understand and keep them reminded.

2. Create routines most especially during outdoor activities in Physical Education Class such as entering the gym or in play area, getting and putting back all the

$\begin{array}{ccc}4.38 & 0.6 & \text { Always } \\ & 4 & \text { Performed }\end{array}$
equipment and in the beginning, during and after of the activities/games to avoid unnecessary accidents

3. Give verbal positive reinforcement to the class.

4. Do health background interview to students and parents and have an intact data of my students for future references.

5. Effectively organize and provide maximum specific activity time in every component of MAPEH within the class period.

$\begin{array}{ccc}4.26 & 0.6 & \text { Always } \\ & 9 & \text { Performed }\end{array}$

class period.

Table 8 shows the indicators about the performance of the non-specialized teachers in MAPEH as a classroom manager or as an adviser. As to their performance in the classroom teachers had their rules and regulations inside the classroom and they clearly explained the consequences and occasionally review the rules and regulations to make sure they clearly understand and keep them reminded $(\mathrm{M}=4.32, \mathrm{SD}=0.65)$. The teachers created routines most especially during outdoor activities in Physical Education Class such as entering the gym or in play area, getting and putting back all the equipment and in the beginning, during and after of the activities/games to avoid unnecessary accidents $(\mathrm{M}=4.38, \mathrm{SD}=0.64)$. Teachers were able to give verbal positive reinforcement to the class $(\mathrm{M}=4.44, \mathrm{SD}=0.67)$. The teachers did health background interview to students and parents and have an intact data of my students for future references $(\mathrm{M}=4.30, \mathrm{SD}=0.71)$. They effectively organized and provided maximum specific activity time in every component of MAPEH within the class period $(\mathrm{M}=4.26, \mathrm{SD}=0.69)$ the weighted mean was 4.34 and the standard deviation was 0.67 . All indicator were interpreted as Always. It was evident the non-specialized teachers of MAPEH were performing as a classroom managers or advisers.

Table 9. Performance of the Non-specialized Teachers in MAPEH in Terms of Coaching and Training Indicator

As a Coach and Trainer

$\begin{array}{ccc}\text { Mean } & \text { SD } & \begin{array}{l}\text { Verbal } \\ \text { Interpretation }\end{array} \\ 3.98 & 1.1 & \text { Often } \\ & 0 & \text { Performed } \\ 3.82 & 1.0 & \text { Often } \\ & 8 & \text { Performed } \\ 3.76 & 1.1 & \text { Often Performed } \\ & 3 & \\ & & \end{array}$
undesirable behavior especially during training and competitions.

1. Attend Seminars in the specific sports where I am assigned to coach/handle.

2. Capable to coach/train my student/player.

3. Create training programs to follow by the players and set proximity control to my players to ceased

$3.66 \quad 1.0 \quad$ Often performed

4. Teach skills and activities that students/player may adopt in real life situation and even outside competition.

5. Motivate my students/player to be active and encourage them to win the competition.

$4.14 \quad 0.9 \quad$ Often Performed 0

3.87: 1.07

Often Performed 


\section{EPRA International Journal of Research and Development (IJRD)}

Table 9 indicates the data collected from the respondents with regards to the performance of the nonspecialized teachers in MAPEH in terms of coaching and training. The teachers attended seminars in the specific sports where they were assigned to coach/to handle $(\mathrm{M}=3.98, \mathrm{SD}=1.10)$. They were capable to coach/ to train the students/players $(\mathrm{M}=3.82, \mathrm{SD}=1.08$, the teacher create training programs to follow by the players and set proximity control to their players to cease undesirable behavior especially during training and competitions $(\mathrm{M}=3.76, \mathrm{SD}=1.13)$. The teacher taught skills and activities that students/players may adopt in real life situation and even outside competition $(\mathrm{M}=3.66, \mathrm{SD}=1.08)$. Lastly, the teachers motivated their students/players to be active and encourage them to win the competition, $(\mathrm{M}=4.14, \mathrm{SD}=0.90)$. The weighted mean and standard deviation is $(\mathrm{M}=3.87, \mathrm{SD}=0.90)$, the verbal interpretation was Often Performed.

Table 10. Performance of the Non-specialized Teachers in MAPEH in term of Handling Ancillary Task

\begin{tabular}{|c|c|c|c|}
\hline $\begin{array}{l}\text { Indicator } \\
\text { As part of my ancillary task }\end{array}$ & Mean & SD & $\begin{array}{c}\text { Verbal } \\
\text { Interpretation }\end{array}$ \\
\hline 1. Committed to my duty even outside the school hours. & 4.32 & 0.65 & $\begin{array}{l}\text { Always } \\
\text { Performed }\end{array}$ \\
\hline 2. Plan my schedule to avoid conflicts. & 4.36 & 0.60 & $\begin{array}{l}\text { Always } \\
\text { Performed }\end{array}$ \\
\hline 3. Can submit reports on time or ahead of time. & 4.34 & 0.63 & $\begin{array}{l}\text { Always } \\
\text { Performed }\end{array}$ \\
\hline $\begin{array}{l}\text { 4. Accept all assignments assigned to me such as; } \\
\text { coordinator, project leader, or non-teaching related. }\end{array}$ & 4.30 & 0.76 & $\begin{array}{l}\text { Always } \\
\text { Performed }\end{array}$ \\
\hline 5. Perform very satisfactory in my performance rating. & 4.40 & 0.70 & $\begin{array}{l}\text { Always } \\
\text { Performed }\end{array}$ \\
\hline Weighted Mean: SD & \multicolumn{3}{|c|}{ 4.34: 0.67} \\
\hline Verbal Interpretation & \multicolumn{3}{|c|}{ Always Performed } \\
\hline
\end{tabular}

Table 10 shows the result in the performance of the non-specialized teachers in MAPEH in terms of ancillary task. The indicators were as follows: As part of the teacher's handling ancillary task, they were committed to their duties even outside of the school hours $(\mathrm{M}=4.32, \mathrm{SD}=0.65)$; they planned their schedule to avoid conflicts ( $\mathrm{M}=4.36, \mathrm{SD}=0.60)$; they submitted reports on time or ahead $(\mathrm{M}=4.34, \mathrm{SD}: 0.63)$; they accepted all assignments assigned such as; coordinator, project leader, or non-teaching related( $\mathrm{M}=4.30, \mathrm{SD}=0.76)$. The teachers performed Very Satisfactorily in their performance rating $(\mathrm{M}=4.40, \mathrm{SD}=0.70)$. The weighted mean was 4.34 and standard deviation was 0.67 , with overall interpretation of Always Performed. It was evident that the teachers were dedicated to their duties and being flexible was also one of the best characteristics of teachers

Effect of Coping Mechanism to the Performance of the Non-Specialized Teachers

Table 11. Effect of Coping Mechanism to the Performance of the Non-specialized Teachers

\begin{tabular}{ccccc}
\hline \multirow{2}{*}{ Coping Mechanism } & $\begin{array}{c}\text { Performance of the Non-specialized } \\
\text { Teachers }\end{array}$ & $\begin{array}{c}\text { F- } \\
\text { value }\end{array}$ & $\begin{array}{c}\text { p- } \\
\text { value }\end{array}$ & Analysis \\
& Classroom Manager & 2.318 & 0.030 & Significant \\
\cline { 2 - 5 } Time Management & Coach and Trainers & 2.322 & 0.030 & Significant \\
\cline { 2 - 5 } Academic Advice and & Ancillary Task & 3.138 & 0.005 & Significant \\
\cline { 2 - 5 } Mentoring & Classroom Manager & 2.779 & 0.015 & Significant \\
\cline { 2 - 5 } & Coach and Trainers & 1.883 & 0.089 & $\begin{array}{c}\text { Not } \\
\text { Significant }\end{array}$ \\
\cline { 2 - 5 } Appraisal Focused & & 3.114 & 0.008 & Significant \\
\cline { 2 - 5 } & Ancillary Task & 10.908 & 0.000 & Significant \\
\hline Emotion Focused & Classroom Manager & 6.584 & 0.000 & Significant \\
\hline & Coach and Trainers & 4.010 & 0.001 & Significant \\
\hline & Ancillary Task & 4.023 & 0.001 & Significant \\
\hline Occupation-focused Coping & Classroom Manager & 3.871 & 0.001 & Significant \\
\cline { 2 - 5 } & Coach and Trainers & 3.963 & 0.001 & Significant \\
\cline { 2 - 5 } & Ancillary Task & 4.147 & 0.001 & Significant \\
\cline { 2 - 5 } & Classroom Manager & 2.144 & 0.048 & Significant \\
\cline { 2 - 5 } & Coach and Trainer & 5.865 & 0.000 & Significant \\
\hline
\end{tabular}


Table 11 shows the result on the Effect of Coping Mechanisms; ; Time Management, Academic Advice and Mentoring, Appraisal Focused, Emotion-focused and Occupation focused to the Performance of the Nonspecialized teachers. The time management as one of the coping mechanisms of the non- specialized teacher in MAPEH significantly effect on their performance as classroom manager $(\mathrm{F}=2.318, \mathrm{p}=0,030)$, coach and trainer $(\mathrm{F}=2.322, \mathrm{p}=0.30)$ and handling ancillary task $(\mathrm{F}=3.3138, \mathrm{p}=0.005)$, the analysis were Significant. The academic advice and mentoring its effect on performance of non- specialized teachers in MAPEH as classroom managers $(F=2.779, p=0.015)$, coach and trainer $(F=1.883, p=0.089)$, and handling ancillary task $(3.114$, $\mathrm{p}=0.008$ ) were Not Significant. In the appraisal focused on the performance of the non-specialized teachers in MAPEH as classroom managers $(\mathrm{F}=10.908, \mathrm{p}=0.000)$, coach and trainer $(\mathrm{F}=6.584, \mathrm{p}=0.000)$, handling ancillary task $(\mathrm{F}=4.010, \mathrm{p}=0.001)$, effects of emotion-focused coping on the performance of teachers as classroom managers $(\mathrm{F}=4.023, \mathrm{p}=0.001)$, as coach and trainer $(\mathrm{F}=3.871, \mathrm{p}=0.001)$ and handling ancillary task $(\mathrm{F}=3.963$, $\mathrm{p}=0.001$, occupation focused on the performance of teachers as classroom managers $(\mathrm{F}=4.147$, $\mathrm{p}=0.001)$, as coach and trainer $(\mathrm{F}=2.144, \mathrm{p}=0.048)$ and in handling ancillary task $(\mathrm{F}=5.865, \mathrm{p}=0.000)$ were Significant. Lastly, the p-value is lower than 0.05 level of significant, therefore the null hypothesis was rejected.

\section{CONCLUSION}

Based on the data collected, the researcher concluded that the performance of the non-specialized had a significant effect on the teachers teaching MAPEH.

The non-specialized teachers studied MAPEH concepts and prepare themselves before facing the learners. They were able to cope with the challenges and performed their roles as classroom managers, trainers/ coaches, and handlers of ancillary tasks. They gained knowledge in teaching MAPEH through specialized trainings and post-graduate study, especially the non-specialized teachers who perform this job.

\section{Recommendation}

In the light of the findings and conclusion of the study, the following recommendations were drawn.

1. The non-specialized teachers may need to have an adequate knowledge and skills in teaching a subject by through trainings to further improve their strategies in teaching the four components of MAPEH.

2. The task may be assigned to a teacher who may have a clear consultation in terms of coaching and training the student athletes and attending to orientation regarding other ancillary tasks to visualize and come up with favorable outcome.

3. The coping mechanism may be enhanced by means of the activities that could develop camaraderie and stress reliever, teaching them to become positive in all aspects.

4. The school may have program for LAC session or learning action cell training to develop fashion in the teaching profession, such as Refresher Training Course for Coaches and Trainers, Honing Teaching Strategies in teaching the 4 components of MAPEH in the simplest yet effective way.

5. Future researches may discover better approaches that could have more coping mechanisms to help teachers struggling in teaching the 4 components of MAPEH and in coaching and training the student athletes.

\section{REFERENCES}

1. Anbar A. and M. Eker, "Work Related Factors That Affect Burnout Among Accounting and Finance Academicians, ” Journal of Industrial Relations and Human Resources, vol. 10, no. 4, pp. 110-137, 2018.

2. Ansari, A., Purtell, K., \& Gershoff, E. (2016). Classroom Age Composition and the School Readiness Of 3- And 4Year-Olds in The Head Start Program. Psychological Science, 27, 53-63. doi:10.1177/0956797615610882

3. Bailliard, A. (2016). Justice, Difference, And The Capability To Function. Journal of Occupational Science, 23, 316. https://doi.org/10.1080/14427591.2014.957886.

4. Baillien, E., Neyens, I., De Witte, H., \& De Cuyper, N. (2010). A Qualitative Study On The Development Of Workplace Bullying: Towards A Three Way Model. Journal Of Community \& Applied Social Psychology, 19, 116.

5. Biesta, G. (2015) What Is Education For? On Good Education, Teacher Judgement, and Educational Professionalism, European Journal Of Education, 50(1), 75-87.

6. Biyani, A.A., Bagheri H., Bayani A. Influence of Gender, Age and Years of Teaching Experience on Burnout. Annals of Biological Research, 2013 4(4): 239- 243.

7. Charles, S. T., Luong, G., Almeida, D. M., Ryff, C., Sturm, M., \& Love, G. (2010). Fewer Ups And Downs: Daily Stressors Mediate Age Differences in Negative Affect. The Journals of Gerontology: Series B: Psychological Sciences And Social Sciences, 65(3), 279-286. doi:10.1093/geronb/gbq002

8. Charles, S. T., Leger, K. A., \& Urban, E. J. (2016). Emotional Experience and Health: What we know, And Where to go from here. in A. D. Ong, C. E. Lo" ckenhoff, A. D. Ong \& C. E. Löckenhoff (Eds.), Emotion, aging, and health (pp. 185-204). 


\section{EPRA International Journal of Research and Development (IJRD)}

9. Chen, Y., Peng, Y., Xu, H., \& O'Brien, W. H. (2017). Age Differences in Stress and Coping: Problem Focused Strategies Mediate the Relationship Between Age and Positive Affect. The International Journal of Aging and Human Development, 86(4), 347-363. doi:10.1177/0091415017720890

10. Darling-Hammond, L. (2006). Constructing 21st century teacher education. Journal of Teacher Education, 57(3), 300-314. https://doi.org/10.1177/0022487105285962

11. Darling-Hammond, L., Furger, R., Shields, P. M., \& Sutcher, L. (2016). Addressing California's Emerging teacher shortage: An analysis of sources and solutions. Palo Alto, CA: Learning Policy Institute Day, C. (2019). How teachers' Individual Autonomy May Hinder Students' Academic Progress and Attainment: Professionalism in practice. British Educational Research Journal. doi:10.1002/berj.3577

12. De Leon, J., \& Balila, E. (2014). Filipino adolescents' coping strategies: A Confirmatory factor analysis. Adventist University of the Philippines Research Journal, 18(2), 73-81. Retrieved from http://www.aup.edu.ph/alumni/wp-content/uploads/R7.pd

13. Delahaij, R., \& Van Dam, K. (2016). Coping style development: The role of Learning Goal OrientationAnd Metacognitive Awareness. Personality and Individual Differences, 57, 57-62.

14. Delahaij, R., \& Van Dam, K. (2017). Coping with acute stress in the military: The influence of coping Style, coping self-efficacy and appraisal emotions. Personality and Individual Differences, 119, 1318. doi:10.1016/j.paid.2017.06.021

15. F. Subon and M. M. Sigie, "Burnout among primary and secondary school teachers in Samarahan District," IOSR Journal of Humanities and Social Science, vol. 21, no. 8, pp. 28-41, 2016.

16. Flores, M. A. (2019). "Unpacking Teacher Quality: Key Issues for Early Career Teachers." In Attracting And Keeping the Best Teachers, edited by A. Sullivan, J. Johnson, and M. Simmons, 15-38. Singapore: Springer

17. Flores, Maria Assunção (2020): Learning to teach: knowledge, competences and support in initial teacherEducation and in the early years of teaching, European Journal of Teacher Education, DOI: $10.1080 / 02619768.2020 .1733828$

18. Fowler, J. L. (2017). Academics at work: mentoring in research, teaching, and Service. International Journal for Academic Development, 22(4), 319-330. doi:10.1080/1360144x.2017.1310105

19. Goldrick, L. (2016). Support from the Start: A 50-State Review of Policies on New Educator InductionAnd Mentoring. Retrieved April 7, 2016, from http://newteachercenter.org/wpcontent/uploads/2016CompleteReportStatePolicies.pdf

20. Guo, Y., Tompkins, V., Justice, L., \& Petscher, Y. (2014). Classroom age Composition and vocabulary Development among at-risk preschoolers. Early Education and Development, 25, 1016-1034. doi:10.1080/ 10409289.2014.893759

21. Gustems-Carnicer, J., \& Calderón, C. (2013). Coping strategies and Psychological wellbeing among Teacher education students. European Journal of Psychology of Education, 28(4), 1127-1140. doi:10.1007/s10212-0120158-x [Crossref],

22. Hegelund, E. R., Grønkjar, M., Osler, M., Dammeyer, J., Flensborg-Madsen, T., \& Mortensen, E.L. (2020). The influence of educational attainment on intelligence. Intelligence, 78, 101419. doi:10.1016/j.intell.2019.101419

23. Hodgen, J. Francis, B., Craig, Taylor, N., B., Archer, L., Mazenod, A.Connolly, P. (2019). Teacher "Quality" and attainment grouping: The role of within-school teacher deployment in social and educational inequality. Teaching and Teacher Education, 77, 183-192. doi:10.1016/j.tate.2018.10.001

24. Jamaludin, I. I., \& You, H. W. (2019). Burnout in relation to Gender, Teaching Experience, and Educational Level among Educators. Education Research International, 2019, 1-5. doi:10.1155/2019/7349135

25. Khan, Kifayat, Tahir Tehsin, Ishfaq Umbreen, Khan Asad: Journal of Business and Tourism December, 2017: A Study to Examine Teachers' Classroom Time Management Strategies at Secondary School Level, Volume 3 ISSN 2520 - 0739 https://www.awkum.edu.pk/jbt/downloads/Volume-03-Number-02-July-Dec-2017/71-83.pdf

26. Killion, Joellen; Bryan, Chris; Clifton, Heather (2020). Coaching Matters, 2nd Edition earning Forward. 504 South Locust Street, Oxford, OH 45056. Tel: 513-523-6029; Fax: 513-523-0638; e-mail: office@learningforward.org; Web site: http://www.learningforward.org

27. Kraft, M. A., Blazar, D., \& Hogan, D. (2018). The Effect of Teacher Coaching on Instruction and Achievement: A Meta-Analysis of the Causal Evidence. Review of Educational Research, 88(4), 547588. doi:10.3102/0034654318759268

28. Le Maistre, C., \& Pare, A. (2008). Whatever it takes: How beginning teachers learn to survive. Teaching and Teacher Education, 559-564. Retrieved from http://www.sciencedirect.com

29. Manship, K., Farber, J., Smith, C., \& Drummond, K. (2016). Case studies of Schools implementing Early elementary strategies: Preschool through third grade alignment and differentiated instruction. Washington, DC: Office of Planning, Evaluation and Policy Development, US Department of Education.

30. Mohammed Mahmoud Baba (2015), Teachers as Classroom Managers: Counselling Psychological Perspective. J. of Education and Policy Review, Vol. 7, No. 2, Pp. $47-54$.

31. Okoro, E. (2018). Assessment of stress related issues \& coping mechanisms Among college Students (Unpublished Maters Thesis). Minnesota State University, Mankato, Minnesota

32. Pereira, R. B. (2017). Towards inclusive occupational therapy: Introducing the CORE approach for

33. Inclusive and occupation-focused practice. Australian Occupational Therapy Journal, 64(6), 429435. doi:10.1111/1440-1630.12394 


\section{EPRA International Journal of Research and Development (IJRD)}

34. Ramune Čiarniene (2014): The Conceptual Model of Time Management, Kaunas University ofTechnology Conference Proceedings MCSER Publishing-Rome, Italy Volume 1 http://citeseerx.ist.psu.edu/viewdoc/download?doi=10.1.1.666.8794\&rep=rep1 \&type $=$ pdf\#page $=42$

35. Reissland, J., \& Manzey, D. (2016). Serial or overlapping processing in Multitasking as individual Preference: Effects of stimulus preview on task switching and concurrent dual-task performance. Acta Psychologica, 168, 27-40.

36. Rilveria, John Robert C. (2018). University of the Philippines-Diliman The Development of the Filipino Coping Strategies Scale: Asia-Pacific Social Science Review 18(1) 2018, pp. 111-126

37. Robotham, D. (2008). Stress among higher education students: Towards a Research agenda. HigherEducation, 56(6), 735-746. doi:10.1007/s10734-008-9137-1 [Crossref],

38. Sreeramareddy, C. $\quad T$., Shankar, $P . \quad$ R., Binu, V. $\quad ~ S .$, Mukhopadhyay, C., Ray, B., \& Menezes, R.G. (2007). Psychological morbidity, sources of stress and coping strategies among undergraduate medical students of Nepal. BMC Medical Education, $7 . \quad$ Retrieved from https://www.ncbi.nlm.nih.gov/pubmed/17678553

39. Thi Thu Trang Tran \& Truong Xuan Do (2020): Student evaluation of teaching: Do teacher age, Seniority, Gender, and qualification matter? Educational Studies, DOI: 10.1080/03055698.2020.1771545

40. Van den Brande, W., Baillien, E., De Witte, H., Vander Elst, T., \& Godderis, L. (2016). The role ofWork Stressors, coping strategies and coping resources in the process of workplace bullying: A systematic review and development of a comprehensive model. Aggression and Violent Behavior, 29, 61-71.

41. Van den Brande, W., Baillien, E., Elst, T. V., De Witte, H., \& Godderis, L. (2019). Coping styles andCoping resources in the work stressors-workplace bullying relationship: A two-wave study. Work \& Stress, 119. doi:10.1080/02678373.2019.1666433

42. Webster, J. R., Beehr, T. A., \& Love, K. (2011). Extending the challenge Hindrance model ofOccupational stress: The role of appraisal. Journal of Vocational Behavior, 79,505-516.

43. Zhang, Y., Zhang, Y., Ng, T. W. H., \& Lam, S. S. K. (2019). Promotion- and Prevention focused coping:A metaanalytic examination of regulatory strategies in the work stress process. Journal of Applied Psychology, 104(10), 1296-1323. https://doi.org/10.1037/apl0000404

44. Lazarus, R. S., \& Folkman, S. (1984). Stress, appraisal, and coping. New York: Springer. [GoogleScholar] 